\title{
Approaching the kinetic inertness of macrocyclic gadolinium(III)-based MRI contrast agents with highly rigid open-chain derivatives
}

\author{
Gyula Tircsó $^{\text {a,b,c }}$, Martín Regueiro-Figueroa ${ }^{\mathrm{d}}$, Viktória Nagy ${ }^{\mathrm{a}}$, Zoltán Garda ${ }^{\mathrm{a}}$, Tamás Garai ${ }^{\mathrm{a}}$, Ferenc \\ Krisztián Kálmán ${ }^{\mathrm{a}}$, David Esteban-Gómez ${ }^{\mathrm{d}}$, Éva Tóth ${ }^{\mathrm{b}}$, Carlos Platas-Iglesias ${ }^{\mathrm{d}}$ \\ ${ }^{a}$ Department of Inorganic and Analytical Chemistry, University of Debrecen, 4010 Debrecen, Egyetem tér 1, \\ Hungary \\ ${ }^{\mathrm{b}}$ Centre de Biophysique Moléculaire, CNRS, rue Charles Sadron, 45071 Orléans, Cedex 2, France \\ ${ }^{\mathrm{c}}$ Le Studium, Loire Valley Institute for Advanced Studies, 1 Rue Dupanloup,45000 Orléans, France \\ ${ }^{\text {d }}$ Departamento de Química Fundamental, Universidade da Coruña, Campus da Zapateira, Rúa da Fraga 10, 15008 \\ A Coruña, Spain
}

Chemistry - A European Journal Volume 22, Issue 3, pages 896-901, January 18, 2016

Issue online: 8 January 2016, Version of record online: 8 January 2016, Accepted manuscript online: 19 November 2015, Manuscript received: 24 September 2015

This is the peer reviewed version of the following article:

Tircsó, G., Regueiro-Figueroa, M., Nagy, V., Garda, Z., Garai, T., Kálmán, F. K., Esteban-Gómez, D., Tóth, E. and Platas-Iglesias, C. (2016), Approaching the kinetic inertness of macrocyclic gadolinium(III)-based MRI contrast agents with highly rigid open-chain derivatives. Chem. Eur. J., 22: 896-901

which has been published in final form at https://doi.org/10.1002/chem.201503836. This article may be used for non-commercial purposes in accordance with Wiley Terms and Conditions for Self-Archiving.

\begin{abstract}
A highly rigid open-chain octadentate ligand $\left(\mathrm{H}_{4} \mathrm{cddadpa}\right)$ containing a diaminocylohexane unit to replace the ethylenediamine bridge of 6,6'-[(ethane-1,2 diylbis\{(carboxymethyl)azanediyl $\})$ bis(methylene)] dipicolinic acid $\left(\mathrm{H}_{4} \mathrm{octapa}\right)$ was synthesized. This structural modification improves the thermodynamic stability of the $\mathrm{Gd}^{3+}$ complex slightly ( $\log K_{\mathrm{GdL}}=20.68$ vs. 20.23 for [Gd(octapa)] ${ }^{-}$) while other MRI-relevant parameters remain unaffected (one coordinated water molecule; relaxivity $r_{1}=5.73 \mathrm{~mm}^{-1} \mathrm{~s}^{-1}$ at $20 \mathrm{MHz}$ and $295 \mathrm{~K})$. Kinetic inertness is improved by the rigidifying effect of the diaminocylohexane unit in the ligand skeleton (half-life of dissociation for physiological conditions is 6 orders of magnitude higher for $[\mathrm{Gd}(\text { cddadpa })]^{-}\left(t_{1 / 2}=1.49 \times 10^{5} \mathrm{~h}\right)$ than for $[\mathrm{Gd}(\text { octapa })]^{-}$. The kinetic inertness of this novel chelate is superior by $2-3$ orders of magnitude compared to non-macrocyclic MRI contrast agents approved for clinical use.
\end{abstract}

Keywords: contrast agents; coordination compounds; gadolinium; lanthanides; NMR imaging

\section{Introduction}

The application of gadolinium(III) complexes as contrast agents in magnetic resonance imaging (MRI) requires stable complexation of the metal ion under physiological conditions to avoid the release of the toxic 
free metal ion. ${ }^{[1,2]}$ Several pathways leading to the potential dissociation of $\mathrm{Gd}^{3+}$ complexes in vivo have been identified: 1) acid-catalyzed dissociation, which is often responsible for the dissociation of complexes with macrocyclic ligands such as $\operatorname{dota}^{4-}($ Scheme 1$\left.){ }^{[3]} 2\right)$ dissociation catalyzed by endogenous metal ions such as $\mathrm{Zn}^{2+}$ and $\mathrm{Cu}^{2+}$, which contributes to the dissociation of contrast agents with non-macrocyclic ligands such as $\mathrm{dtpa}^{5-} ;{ }^{[4]}$ and 3 ) dissociation assisted by endogenous ligands like citrate, phosphate or bicarbonate, which is also important for non-macrocyclic contrast agents. ${ }^{[5]}$ Complexes of linear ligands generally present faster dissociation kinetics than the macrocyclic counterparts, although some macrocyclic $\mathrm{Gd}^{3+}$ complexes were shown to undergo rather fast dissociation. ${ }^{[6]}$ Low basicity of the $\mathrm{Gd}^{3+}$ complex has been identified as an important factor to improve its kinetic inertness. For instance, dota-tetraamide $\mathrm{Gd}^{3+}$ complexes were shown to be considerably more inert than $[\mathrm{Gd}(\mathrm{dota})]^{-}$, which has been attributed to the low basicity of the amide oxygen atom that makes proton transfer to the ring nitrogen very unlikely. ${ }^{[7]}$ Another important factor is rigidity, which is likely responsible for the higher kinetic inertness of macrocyclic complexes. For instance, $\mathrm{cdta}^{4-}$, which contains a rigid diaminocylohexane unit, forms considerably more inert $\mathrm{Ln}^{3+}$ and $\mathrm{Mn}^{2+}$ complexes than the edta ${ }^{4-}$ analogues. ${ }^{[8,9]}$ The rigidity of the backbone in numerous bishydrated $\mathrm{Gd}^{3+}$ complexes of ligands derived from $\mathrm{cdta}^{4-}$ and 2,6-bis(aminomethyl)pyridine was also found to play an important role; however these systems were either similar or just slightly better than the non-macrocyclic MRI contrast agents available in the market. ${ }^{[10,11]}$ The beneficial effect of alpha-C-substitution on the thermodynamic and kinetic properties of $\mathrm{Y}^{3+}$ complexes $\left(\mathrm{Y}^{3+}\right.$ behaves very similarly to $\left.\mathrm{Gd}^{3+}\right)$ formed with dtpa-like ligands is also well documented ${ }^{[12]}$ On the other hand, a rigid cross-bridge macrocyclic ligand was recently shown to provide exceptionally inert $\mathrm{Ln}^{3+}$ complexes, highlighting again the impact of ligand rigidity on the kinetic inertness of macrocyclic complexes as well. ${ }^{[13]}$
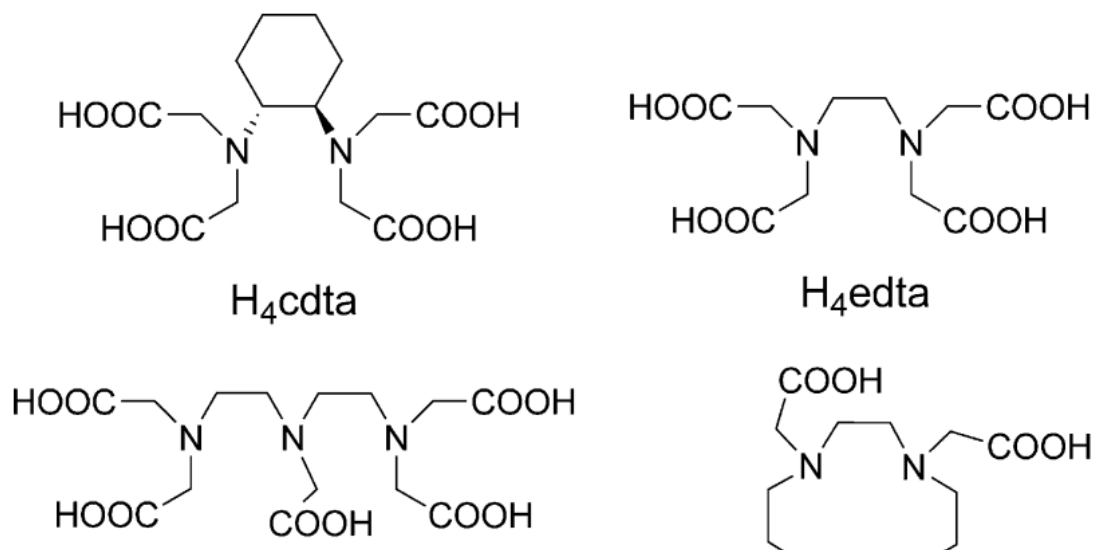

$\mathrm{H}_{5} \mathrm{dtpa}$

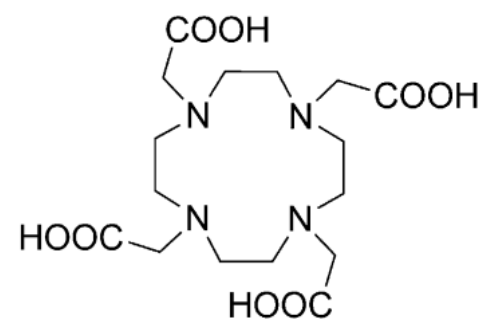<smiles>O=C(O)CN(CC(=O)O)C1CCCCC1N(CC(=O)O)Cc1cccc(C(=O)O)n1</smiles>

$\mathrm{H}_{4}$ dota<smiles>O=C(O)CN(CCN(CC(=O)O)Cc1cccc(C(=O)O)n1)CC(=O)O</smiles>

$\mathrm{H}_{4}$ cddadpa

$\mathrm{H}_{4}$ Octapa

Scheme 1. Ligands discussed in the present work. 
The non-macrocyclic octadentate ligand 6,6'-[(ethane-1,2-diylbis $\{($ carboxymethyl)azanediyl $\})$ bis (methylene)]dipicolinic acid ( $\mathrm{H}_{4} \mathrm{octapa}$, Scheme 1) forms $\mathrm{Ln}^{3+}$ complexes with high thermodynamic stability ( $\log K=19.9-20.5$ depending on the $\operatorname{Ln}^{3+}$ ion). ${ }^{[14,15]}$ Furthermore, [Gd(octapa) $]^{-}$contains a coordinated water molecule that results in ${ }^{1} \mathrm{H}$ relaxivities similar to those of commercially available contrast agents, such as $[\mathrm{Gd}(\mathrm{dota})]^{-}$or $[\mathrm{Gd}(\mathrm{dtpa})]^{2-}{ }^{[16]}$ However, kinetic studies showed that $[\mathrm{Gd}(\text { octapa })]^{-}$is considerably more labile than the edta ${ }^{4-}$ and $\mathrm{dtpa}^{5-}$ counterparts, which is unacceptable for practical applications. ${ }^{[15]}$ Herein, we report the octadentate ligand $\mathrm{H}_{4}$ cddadpa, which incorporates a rigid diaminocyclohexane unit instead of the ethylenediamine linker of $\mathrm{H}_{4}$ octapa. The corresponding $\mathrm{Gd}^{3+}$ complex retains a coordinated water molecule while providing improved relaxivities and thermodynamic stability with respect to [Gd(octapa) $]^{-}$. Most importantly, [Gd(cddadpa) $]^{-}$displays an unprecedented kinetic inertness for an open-chain system.

Ligand $\mathrm{H}_{4}$ cddadpa was synthetized in four steps starting from methyl 6-formylpicolinate (1), which was obtained in three steps from commercially available pyridine-2,6-dicarboxylic acid. ${ }^{[15]}$ Reaction of $\mathbf{1}$ with $(1 R, 2 R)$-diaminocylohexane gave Schiff base $\mathbf{2}$, which was reduced with $\mathrm{NaBH}_{4}$ to give amine $\mathbf{3}$ (Scheme 2). $\mathrm{N}$-alkylation of $\mathbf{3}$ with tert-butyl-2-bromoacetate at room temperature in acetonitrile solution and subsequent deprotection of the methyl and tert-butyl esters with $6 \mathrm{~m} \mathrm{HCl}$ gave the $\mathrm{H}_{4}$ cddadpa ligand, which was isolated with an overall yield of $37 \%$ over the four steps (the experimental details of synthesis of $\mathbf{2}$ and $\mathbf{3}$ are included in the Supporting Information). The [Ln(cddadpa) ${ }^{-}$complexes ( $\mathrm{Ln}=\mathrm{Eu}$ or $\mathrm{Gd}$ ) were prepared in aqueous solution by reaction of equimolar amounts of the ligand and $\operatorname{Ln}(\mathrm{OTf})_{3}$ followed by adjustment of the $\mathrm{pH}$ to about 7 with aqueous $\mathrm{NaOH}$. The HR-ESI mass spectra of the complexes present a peak due to the [Ln(cddadpa) $]^{-}$entities that confirms the formation of the complexes (Figure S5 and S6, Supporting Information). The absorption and CD spectra of the Gd complex confirm the formation of the optically active complex (Figure S7, Supporting Information).
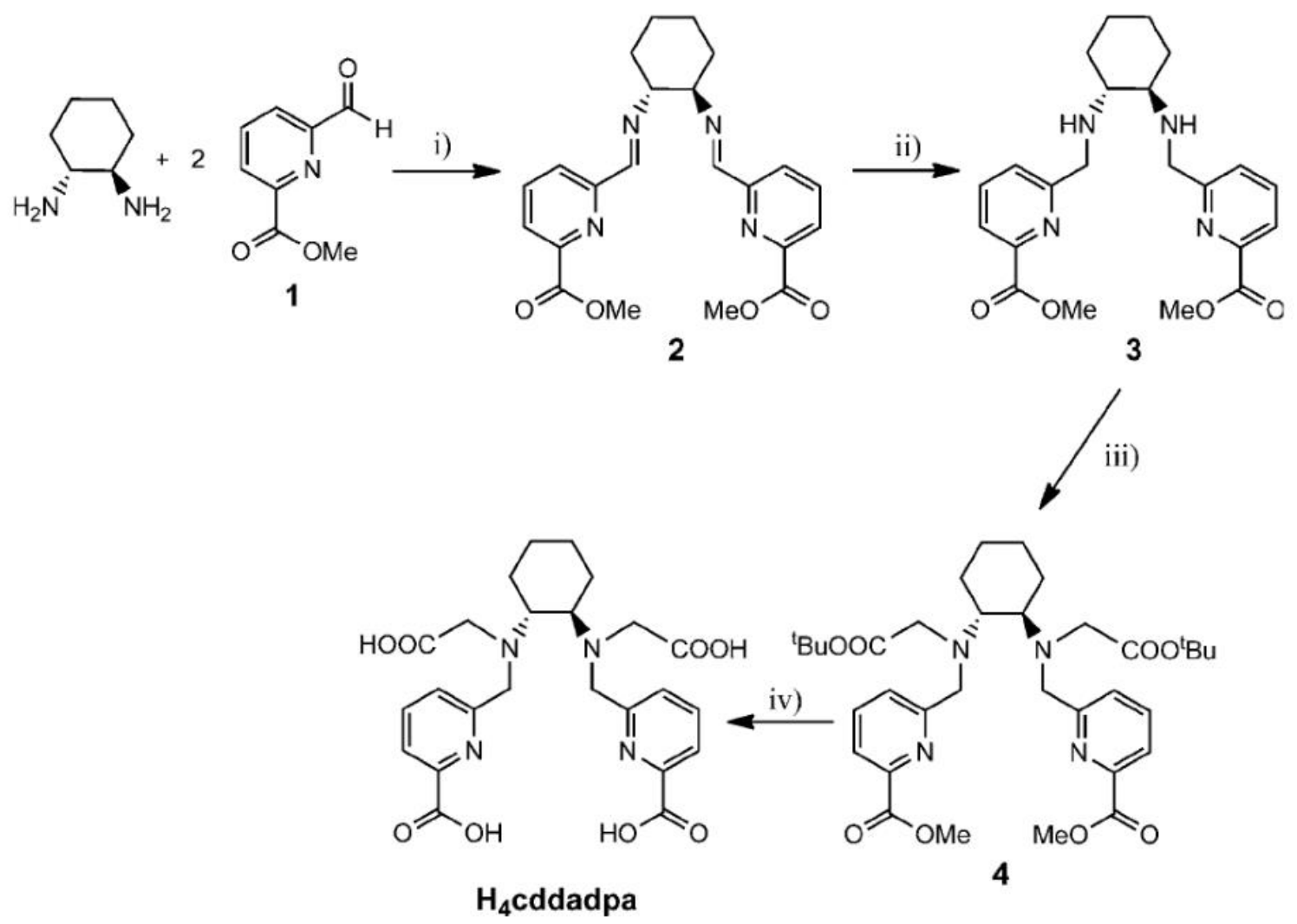

Scheme 2. Synthesis of $\mathrm{H}_{4}$ cddadpa. Reagents and conditions: i) $\mathrm{MeOH}$, reflux, 4 h, 84 \%; ii) $\mathrm{NaBH}_{4}, \mathrm{MeOH} 91 \%$; iii) tert-butyl-2-bromoacetate (2.1 equiv), $\mathrm{K}_{2} \mathrm{CO}_{3}$, acetonitrile, room temperature, $4 \mathrm{~d}$ and $45^{\circ} \mathrm{C}, 3 \mathrm{~d}, 65 \%$; iv) $6 \mathrm{~m} \mathrm{HCl}$, reflux, $24 \mathrm{~h}, 75 \%$. See the Supporting Information for experimental details. 
Equilibrium studies to obtain the ligand protonation constants and the stability constant of the $\mathrm{Gd}^{3+}$ complex were carried out by pH-potentiometry (Figure S8 and S9, Supporting Information). The first protonation constant (Table 1) of cddadpa $^{4-}$ is ca. $0.8 \log K$ unit higher than that of the related octapa ${ }^{4-}{ }^{[15]}$ The small differences in the basicity of these ligands may be attributed to the structural rigidity brought by the cyclohexyl bridge compared to the more flexible ethylene bridging unit. A similar increase in the basicity of the nitrogen atom was also observed for cdta $^{4-}$ when comparing its $\log K_{1}{ }^{\mathrm{H}}$ value to that of edta ${ }^{4-}$. ${ }^{[17]}$ Similar to the $\left[\mathrm{Gd}(\text { octapa) }]^{-}\right.$complex, it was not possible to determine the stability constant of $[\mathrm{Gd} \text { (cddadpa) }]^{-}$by using solely $\mathrm{pH}$ potentiometry, as the complex is nearly quantitatively formed even at $\mathrm{pH} 1.8$. Therefore, the $\mathrm{pH}$ potentiometric titration data were complemented by ${ }^{1} \mathrm{H}$ relaxometric titrations (the relaxivity $\mathrm{pH}$ profile is included in the Supporting Information). The relaxivity of [Gd(cddadpa) $]^{-}$remains constant in the $\mathrm{pH}$ range of about 12.0-2.0, and increases below about 2.0 due to the dissociation of the complex (Figure S9, Supporting Information). By knowing the relaxivities of the $\mathrm{Gd}^{3+}$ aqua ion and [Gd(cddadpa)] $]^{-}$, the stability constant of the complex could be determined (Table 1). Owing to the increased basicity of cddadpa ${ }^{4-}$, the stability of its $\mathrm{Gd}^{3+}$ complex is increased by ca $0.4 \log K$ units in comparison to [Gd(octapa)] ${ }^{-}$and it is close to that of $[\mathrm{Gd}(\mathrm{dtpa})]^{2-}$ (Table 1), which is a commercial open-chain MRI contrast agent used in clinical practice ${ }^{[18]}$ Moreover, the stability of $[\mathrm{Gd}(\mathrm{cddadpa})]^{-}$is comparable to or slightly lower than those of the $\mathrm{Gd}^{3+}$ complexes formed with macrocyclic do3a $\mathrm{a}^{3-}$ and its derivatives used as commercial contrast agents (hpdo $3 \mathrm{a}^{3-}$ and do3a-butrol $\left.{ }^{3-}\right) \cdot{ }^{[19]}$ Given the considerably lower basicity of cddadpa ${ }^{4-}$, the conditional stability constant of [Gd(cddadpa) $]^{-}$will be higher near physiological conditions, despite the comparable stability constants of the complexes. This is demonstrated by comparing the pGd values calculated as proposed by Raymond and co-workers (Table 1). ${ }^{[20]}$ The pGd value obtained for [Gd(cddadpa)] ${ }^{-}$is slightly higher than that determined for $[\mathrm{Gd}(\mathrm{dtpa})]^{2-}$ (the increase is only $0.2 \mathrm{pGd}$ units) but clearly higher than those of complexes with macrocyclic ligands such as [Gd(do3a)] (ca. $3.8 \mathrm{pGd}$ units). This confirms that $[\mathrm{Gd}(\mathrm{cddadpa})]^{-}$has the highest stability among the complexes compared in Table 1 at physiological $\mathrm{pH}$.

Table 1. Protonation constants of cddadpa ${ }^{4-}$ and related ligands and stability constants and pGd values of their $\mathrm{Gd}^{3+}$ complexes $\left(25^{\circ} \mathrm{C}, 0.15 \mathrm{~m} \mathrm{NaCl}\right)$.

\begin{tabular}{|c|c|c|c|c|}
\hline & cddadpa $^{4-}$ & octapa $^{4-[a]}$ & $\mathrm{dtpa}^{5-[\mathrm{b}]}$ & $\operatorname{do} 3 \mathrm{a}^{3-[\mathrm{c}, \mathrm{d}]}$ \\
\hline $\log K_{1}^{\mathrm{H}}$ & $9.35(2)$ & 8.52 & 9.93 & 11.99 \\
\hline $\log K_{2}^{\mathrm{H}}$ & $5.66(3)$ & 5.40 & 8.37 & 9.51 \\
\hline $\log K_{3}^{\mathrm{H}}$ & $4.20(3)$ & 3.65 & 4.18 & 4.31 \\
\hline $\log K_{4}^{\mathrm{H}}$ & $3.72(3)$ & 2.97 & 2.71 & 3.63 \\
\hline $\log K_{5}{ }^{\mathrm{H}}$ & $2.62(4)$ & 1.66 & 2.00 & 1.84 \\
\hline$\sum \log K_{\mathrm{i}}^{\mathrm{H}}$ & 25.55 & 22.20 & 27.19 & 31.26 \\
\hline $\log K_{\mathrm{GdL}}$ & $20.68(9)^{[\mathrm{e}]}$ & $20.23^{[\mathrm{f}]}$ & 22.03 & 21.56 \\
\hline $\log K_{\mathrm{GdHL}}$ & $2.38(2)^{[\mathrm{e}]}$ & - & 1.96 & - \\
\hline pGd & 19.66 & 19.23 & 19.44 & 15.81 \\
\hline
\end{tabular}

[a] Ref. [15]. [b] Ref. [18]. [c] Ref. [21]. [d] Protonation and stability constants were determined by using $0.1 \mathrm{~m} \mathrm{KCl}$ ionic strength. All these constants are expected to be considerably lower in $0.15 \mathrm{~m} \mathrm{NaCl}$, but the pGd value will be very likely similar to the one calculated by using the data corresponding to $0.1 \mathrm{~m} \mathrm{KCl}$ ionic strength. [e] Determined by simultaneous fitting of relaxometric and $\mathrm{pH}$ potentiometric data. [f] Determined by relaxometric titration.

Kinetic inertness is a key parameter for safe application of a $\mathrm{Gd}^{3+}$ complex as a contrast agent, since the complexes injected to the body must remain intact. In the light of the encouraging stability data discussed above, the kinetic inertness of $[\mathrm{Gd}(\mathrm{cddadpa})]^{-}$was characterized by studying the rate of the metal exchange 
reaction occurring with $\mathrm{Cu}^{2+} \cdot \mathrm{Cu}^{2+}$ is typically the most efficient among the physiologically relevant metal ions to promote transmetalation reactions with $\mathrm{Gd}^{3+}$ complexes. ${ }^{[4,5]}$ The pseudo-first-order rate constants determined for the exchange reaction between $[\mathrm{Gd}(\mathrm{cddadpa})]^{-}$and $\mathrm{Cu}^{2+}$ ion are shown in Figure 1 . The $k_{\text {obs }}$ values increase with increasing concentrations of both $\mathrm{H}^{+}$and $\mathrm{Cu}^{2+}$ ions, which can be rationalized by considering three dissociation pathways: spontaneous, proton-assisted (via the formation of a protonated [GdH(cddadpa)] intermediate) and metal-assisted (through the formation of a dinuclear reaction intermediate). These dissociation pathways are characterized by rate constants $k_{0}\left[\mathrm{~s}^{-1}\right], k_{1}\left[\mathrm{~m}^{-1} \mathrm{~s}^{-1}\right]$, and $k_{3}\left[\mathrm{~m}^{-1} \mathrm{~s}^{-1}\right]$, respectively. The overall map of dissociation pathways, the expression used for the pseudofirst-order rate constant $\left(k_{\mathrm{obs}}\right)$ and the equations employed for data refinement are included in the Supporting Information.

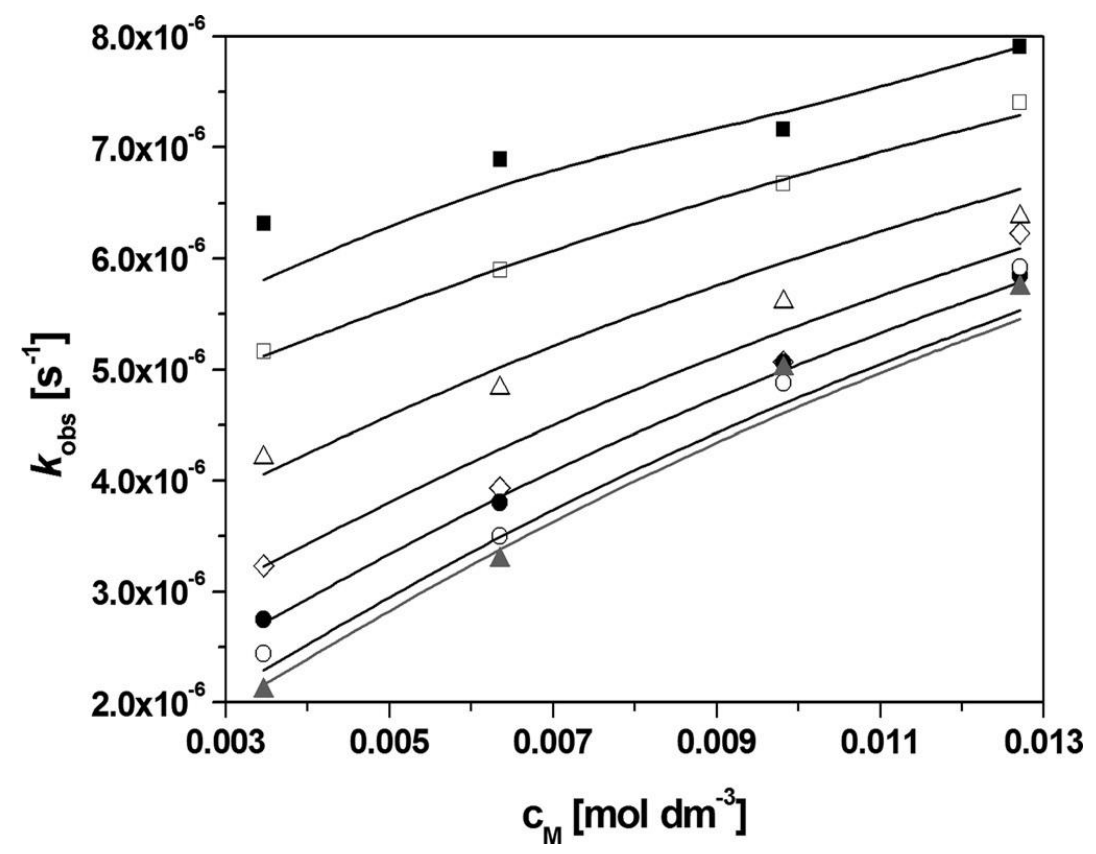

Figure 1. Plot of the pseudo-first-order rate constants measured as function of $\mathrm{Cu}^{2+}$ ion concentration and $\mathrm{pH}(50$ mm DMP, $25^{\circ} \mathrm{C}, 0.15 \mathrm{M} \mathrm{NaCl}, \mathrm{pH} 3.38,3.51,3.70,3.96,4.21,4.64$ and 4.94 downwards).

The rate constants are compared with those of the $\mathrm{Gd}^{3+}$ complexes formed with octapa ${ }^{4-}$, $\mathrm{dtpa}^{5-}$, and do $3 \mathrm{a}^{3-}$ in Table 2. The rate constant of the proton-assisted dissociation $\left(k_{1}\right)$ of [Gd(cddadpa) $]^{-}$decreases by nearly three orders of magnitude when compared to the corresponding value for [Gd(octapa) $]^{-}$. Moreover, $k_{1}$ is more than 30 times smaller for $[\mathrm{Gd}(\mathrm{cddadpa})]^{-}$than that for $[\mathrm{Gd}(\mathrm{dtpa})]^{2-}$, and very similar to that of $[\mathrm{Gd}(\mathrm{do} 3 \mathrm{a})]$. On the other hand, the rate constant characterizing the direct attack of the $\mathrm{Cu}^{2+}$ ion on the complex, $k_{3}$, is more than three orders of magnitude smaller for [Gd(cddadpa) $]^{-}$than for $[\mathrm{Gd}(\mathrm{dtpa})]^{2-}$ (endogenous metal ions are known not to affect the dissociation of $\mathrm{Ln}^{3+}$ complexes of do3a $\mathrm{a}^{3-}$ or dota ${ }^{4-}$ ligands) ${ }^{[19]} \mathrm{A}$ comparison of the dissociation half-lives, $t_{1 / 2}$, calculated near physiological conditions ( $\mathrm{pH} 7.4$, $c_{\mathrm{Cu} 2+}=1 \mu \mathrm{m}$; Table 2) confirms the remarkable kinetic inertness of [Gd(cddadpa) ${ }^{-}$, which results from the integration of a highly rigid diaminocyclohexane unit in the ligand skeleton. The deceleration of the dissociation is a consequence of the strained structure of the chelate, as demetalation requires structural rearrangements that will proceed more slowly for complexes with non-flexible ligands. ${ }^{[10-12,22]}$ Indeed, the ${ }^{1} \mathrm{H}$ NMR spectrum of the [Eu(cddadpa) $]^{-}$complex recorded in $\mathrm{D}_{2} \mathrm{O}$ solution shows a very rigid structure (Figure 2). A total of 22 paramagnetically shifted signals in the range circa +28 to $-14 \mathrm{ppm}$ are observed (at $25^{\circ} \mathrm{C}$ ), which corresponds to a $C_{1}$ symmetry of the complex. This is in contrast with the more flexible structure of [Ln(octapa) $]^{-}$complexes $(\mathrm{Ln}=\mathrm{La}, \mathrm{Ce}, \mathrm{Pr}, \mathrm{Nd}$, or $\mathrm{Sm})$ reflected by an effective $C_{2}$ symmetry. ${ }^{[16]}$ 
Table 2. Rate and equilibrium constants characterizing the dissociation of the $\mathrm{Gd}^{3+}$ complexes of cddadpa ${ }^{4-}$, octapa $^{4-}, \mathrm{dtpa}^{5-}$, and $\mathrm{do}_{3 \mathrm{a}^{3-}}\left(25^{\circ} \mathrm{C}\right)$.

\begin{tabular}{lcccc}
\hline & cddadpa $^{4-}$ & octapa $^{4-[\mathrm{a}]}$ & $\mathrm{dtpa}^{5-[\mathrm{b}]}$ & $\mathrm{do3a}^{3-[\mathrm{c}]}$ \\
\hline$k_{1}\left(\mathrm{M}^{-1} \mathrm{~s}^{-1}\right)$ & $0.016 \pm 0.002$ & 11.8 & 0.58 & $0.023,0.025^{[\mathrm{f}]}$ \\
$k_{2}\left(\mathrm{M}^{-2} \mathrm{~s}^{-1}\right)$ & - & $2.5 \times 10^{4}$ & $9.7 \times 10^{4}$ & - \\
$k_{3}{ }^{\mathrm{Cu}}\left(\mathrm{M}^{-1} \mathrm{~s}^{-1}\right)$ & $6.8 \pm 0.4 \times 10^{-4}$ & 22.5 & 0.93 & - \\
$k_{6}{ }^{\mathrm{Cu}}\left(\mathrm{M}^{-2} \mathrm{~s}^{-1}\right)$ & - & $5.0 \times 10^{9}$ & - & - \\
$K_{\mathrm{H}}{ }^{[\mathrm{d}]}$ & $737 \pm 435$ & 398 & 100 & - \\
$K_{\mathrm{CuGdL}}$ & $48 \pm 8$ & - & 13 & - \\
$t_{1 / 2}(\mathrm{~h})^{[\mathrm{e}]}$ & $1.49 \times 10^{5}$ & 0.15 & 202 & $2.10 \times 10^{5}$, \\
& & & & $1.93 \times 10^{5[\mathrm{f}]}$ \\
\hline
\end{tabular}

[a] Ref. [15]. [b] Ref. [4]. [c] Ref. [21]. [d] A $\log K_{\mathrm{H}}$ value of 2.38(2) was determined by pH-potentiometry. [e] $t_{1 / 2}=\ln 2 / k_{\mathrm{obs}}$ where $k_{\mathrm{obs}}$ was calculated by using $\mathrm{pH} 7.4$ and $\mathrm{c}_{\mathrm{Cu} 2+}=1 \mu \mathrm{m}$. [f] Ref. [23].

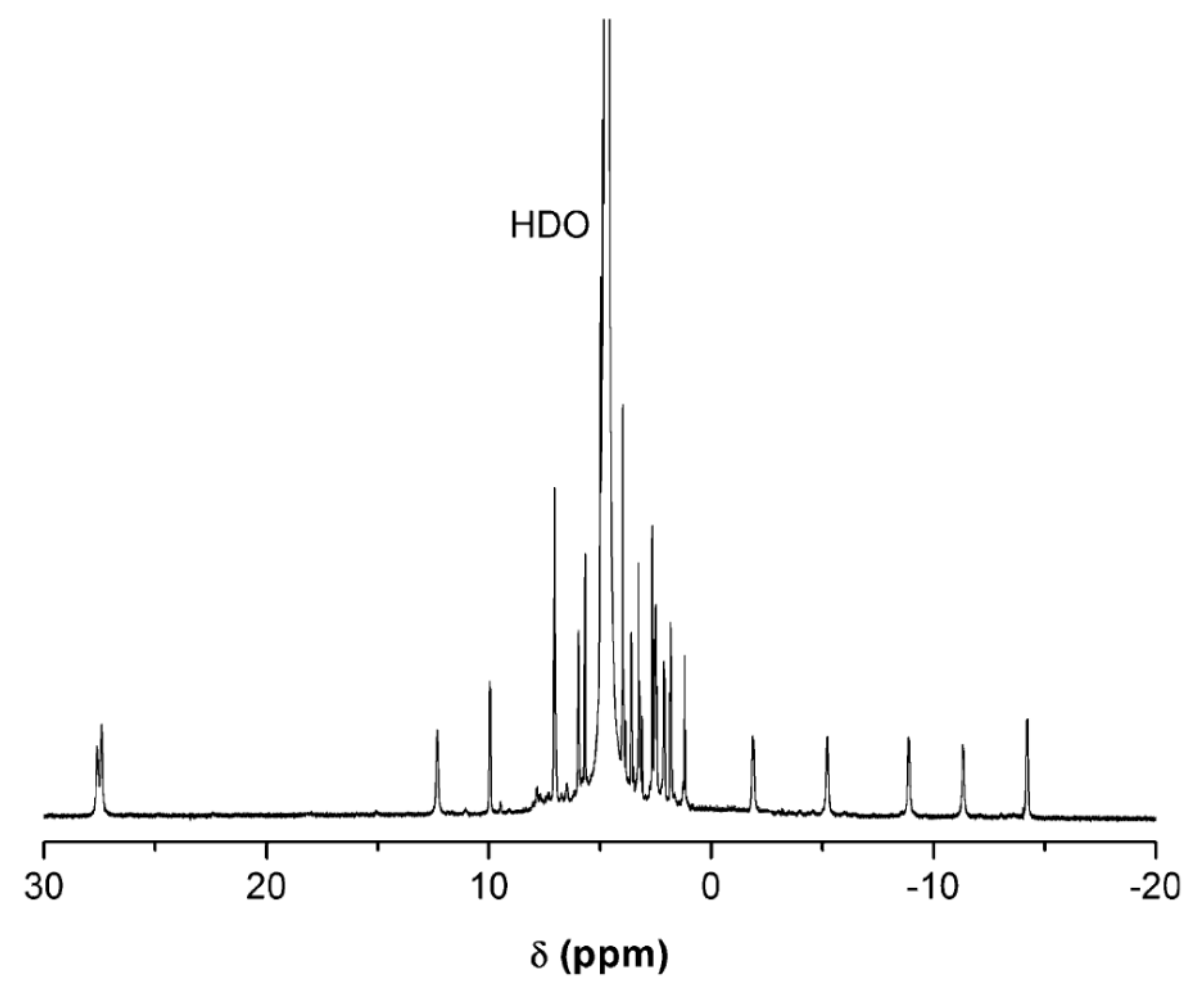

Figure 2. ${ }^{1} \mathrm{H}$ NMR spectrum of $[\mathrm{Eu}(\mathrm{cddadpa})]^{-}$recorded in $\mathrm{D}_{2} \mathrm{O}$ solution $\left[300 \mathrm{MHz}, 25{ }^{\circ} \mathrm{C}, \mathrm{pD} 7.0\right]$.

The emission spectra of [Eu(cddadpa) $]^{-}$recorded in $\mathrm{H}_{2} \mathrm{O}$ and $\mathrm{D}_{2} \mathrm{O}$ solutions show the ${ }^{5} \mathrm{D}_{0} \rightarrow{ }^{7} \mathrm{~F} J$ transitions expected for this metal ion, with maxima at $580(J=0), 593(J=1), 615(J=2), 652(J=3)$, and $685 \mathrm{~nm}(J=4)$ (Figure S10, Supporting Information). The emission lifetimes of the ${ }^{5} \mathrm{D}_{0}$ excited state recorded in $\mathrm{H}_{2} \mathrm{O}$ and $\mathrm{D}_{2} \mathrm{O}$ are 0.58 and $2.15 \mathrm{~ms}$, respectively. These values provide hydration numbers of $q=1.20$ and 1.05 using the methods developed by Beeby ${ }^{[24]}$ and Horrocks, ${ }^{[25]}$ respectively, which points to the presence of one water molecule coordinated to the $\mathrm{Ln}^{3+}$ ion. 
The relaxivity $\left(r_{1 \mathrm{p}}\right)$ measured for $[\mathrm{Gd}(\mathrm{cddadpa})]^{-}$at $20 \mathrm{MHz}$ and $25^{\circ} \mathrm{C}(\mathrm{pH} 7.4)$ amounts to $5.6 \mathrm{~mm}^{-1} \mathrm{~s}^{-1}$, a value that is ca. $12 \%$ higher than that measured under the same conditions for [Gd(octapa) ]-, and ca. $19 \%$ higher than those reported for the commercially available contrast agents $[\mathrm{Gd}(\mathrm{dota})]^{-}$and $[\mathrm{Gd}(\mathrm{dtpa})]^{-}$ (Figure 3). The relaxivity is somewhat lower at $37^{\circ} \mathrm{C}\left(4.5 \mathrm{~mm}^{-1} \mathrm{~s}^{-1}\right)$, which indicates that it is limited by fast rotation. However, the $r_{1 \mathrm{p}}$ value obtained at $37^{\circ} \mathrm{C}$ is still higher than those of $\left[\mathrm{Gd}(\text { octapa) }]^{-}\left(3.9 \mathrm{~mm}^{-1} \mathrm{~s}^{-1}\right)\right.$, $[\operatorname{Gd}(\text { dota })]^{-}\left(3.8 \mathrm{~mm}^{-1} \mathrm{~s}^{-1}\right)$, and $[\mathrm{Gd}(\mathrm{dtpa})]^{-}\left(4.0 \mathrm{~mm}^{-1} \mathrm{~s}^{-1}\right)$. This is likely related to the rigid nature of [Gd(cddadpa) $]^{-}$, which leads to a slightly longer rotational correlation time.

In conclusion, we have shown that the strained, open-chain ligand cddadpa ${ }^{4-}$ forms a $\mathrm{Gd}^{3+}$ complex with high thermodynamic stability and unprecedented kinetic inertness for a linear chelate, which becomes comparable to those of macrocyclic complexes. The incorporation of the rigid diaminocyclohexane unit does not alter the hydration number of the complex and increases slightly its ${ }^{1} \mathrm{H}$ relaxivity. Our results highlight the importance of rigidification in the ligand backbone to design $\mathrm{Gd}^{3+}$-based contrast agents with improved features. The [Gd(cddadpa)] complex is a very promising candidate for further development of safer MRI contrast agents.

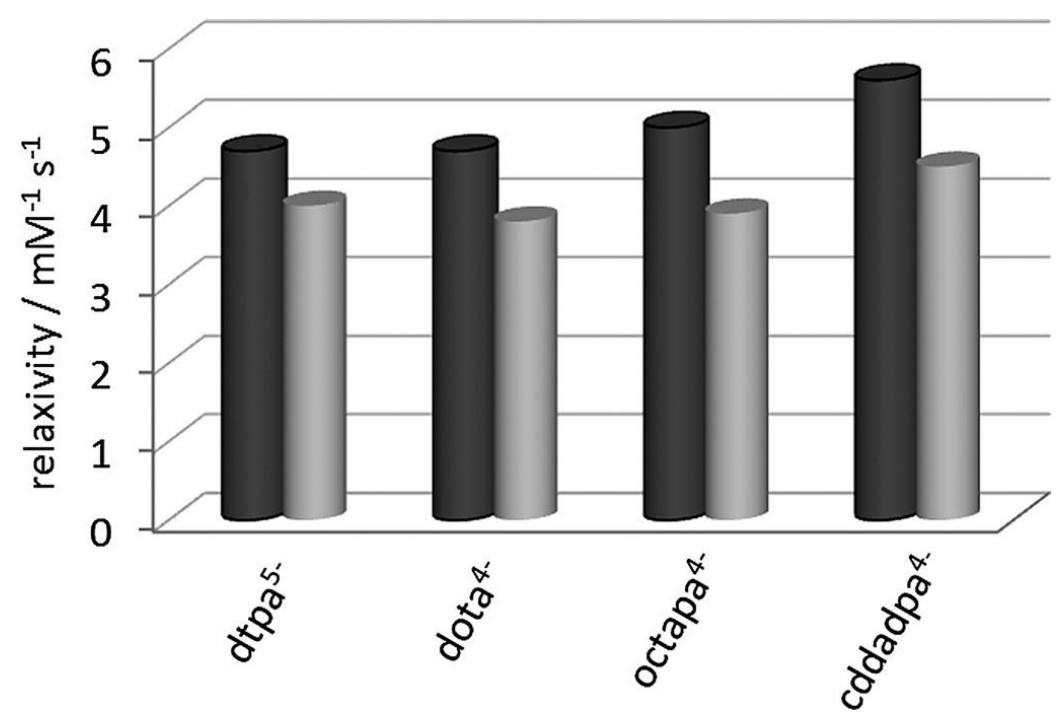

Figure 3. Plot of the relaxivity, $r_{1 \mathrm{p}}$, for selected $\mathrm{Gd}^{3+}$ complexes at $20 \mathrm{MHz}$ and $25^{\circ} \mathrm{C}$ (dark gray) and $37^{\circ} \mathrm{C}$ (light gray).

\section{Experimental Section}

\section{General}

Chemicals were purchased from commercial sources and used without further purification. $\mathrm{SiO}_{2}$ (Fluka, pore size $60 \AA$ A , 70-230 mesh) was used for preparative column chromatography. Compound $\mathbf{3}$ was synthesized as described previously. ${ }^{[26] 1} \mathrm{H}$ and ${ }^{13} \mathrm{C}$ NMR spectra were recorded at $25{ }^{\circ} \mathrm{C}$ on Bruker Avance $500 \mathrm{MHz}$ and Bruker Avance $300 \mathrm{MHz}$ spectrometers. High-resolution ESI-TOF mass spectra were recorded using a LCQ-q-TOF Applied Biosystems QSTAR Elite spectrometer both in the positive and negative modes. Elemental analyses were carried out on a ThermoQuest Flash EA 1112 elemental analyzer. IR spectra were recorded using a Bruker Vector 22 spectrophotometer equipped with a Golden Gate Attenuated Total Reflectance (ATR) accessory (Specac). Excitation and emission spectra were recorded on a PerkinElmer LS50B spectrometer. Luminescence lifetimes were calculated from the monoexponential fitting of the average 
decay data, and they are averages of at least 3-5 independent determinations. Hydrations numbers $q$ were obtained using equation (1), where $\tau_{\mathrm{H} 2 \mathrm{O}}$ and $\tau_{\mathrm{D} 2 \mathrm{O}}$ respectively refer to the measured luminescence decay lifetimes (in $\mathrm{ms}$ ) in water and deuterated water:

$$
q_{\mathrm{Eu}}=A\left(\frac{1}{\tau_{\mathrm{H}_{2} O}}-\frac{1}{\tau_{D_{2} \mathrm{O}}}-B\right)
$$

where $A$ and $B$ are empirical constants that take values of $A=1.2$ and $B=0.25^{[23]}$ or $A=1.11$ and $B=0.31 .^{[25]}$

UV/Vis spectra were recorded on a Perkin Elmer Lambda 900 spectrophotometer using a $1.0 \mathrm{~cm}$ path quartz cell. CD spectra were recorded on a Jasco J-815 circular dichroism spectropolarimeter with a stop-flow accessory.

\section{Equilibrium measurements}

The concentration of the $\mathrm{H}_{4}$ cddadpa ligand as well as its protonation constants were determined by using $\mathrm{pH}$ potentiometric titrations. Methrohm 785 DMP Titrino equipped with a Metrohm 6.0233.100 combined electrode was used to measure the $\mathrm{pH}$ in titration experiments. For the $\mathrm{pH}$ calibration of the electrode, $\mathrm{KH}$ phthalate $(\mathrm{pH} 4.005)$ and borax $(\mathrm{pH} 9.177)$ buffers were used. The calculation of $\left[\mathrm{H}^{+}\right]$from the measured $\mathrm{pH}$ values was performed with the use of the method proposed by Irving et al. ${ }^{[27]}$ by titrating a $0.01 \mathrm{~m} \mathrm{HCl}$ solution $(I=0.15 \mathrm{~m} \mathrm{NaCl})$ with a standardized $\mathrm{NaOH}$ solution. The differences between the measured and calculated $\mathrm{pH}$ values were used to obtain the $\left[\mathrm{H}^{+}\right]$concentrations from the $\mathrm{pH}$-data collected in the titrations. The ion product of water was determined $\left(\mathrm{p} K_{\mathrm{w}}=13.820\right)$ from the same experiment in the $\mathrm{pH}$ range 11.40 12.00. The ionic strength in the titrated and thermostated (at $25^{\circ} \mathrm{C}$ ) samples of $6.00 \mathrm{~mL}$ was kept constant and set to $0.15 \mathrm{~m} \mathrm{NaCl}$. The samples were stirred by a mechanical stirrer and kept under inert gas atmosphere $\left(\mathrm{N}_{2}\right)$ to avoid the effect of $\mathrm{CO}_{2}$. The protonation constants of the ligand were determined by direct $\mathrm{pH}$ potentiometric titration by titrating $2.28 \mathrm{~mm}$ ligand solutions with a standardized $\mathrm{NaOH}$ solution in the $\mathrm{pH}$ range of 1.80-12.00. The protonation constants of the ligand and the stability constant of its $\mathrm{Gd}^{3+}$ complex are defined as $K_{\mathrm{HiL}}=[\mathrm{HiL}] /\left[\mathrm{H} i_{-1} \mathrm{~L}\right]\left[\mathrm{H}^{+}\right]$and $\left.K_{\mathrm{GdL}}=[\mathrm{GdL}] /\left[\mathrm{Gd}^{3+}\right][\mathrm{L}]\right)$. The determination of the stability constant of $[\mathrm{Gd} \text { (cddadpa) }]^{-}$complex was carried out using the ${ }^{1} \mathrm{H}$-relaxometric method by measuring the longitudinal relaxation times of the samples acquired in a wide $\mathrm{pH}$ range $(\mathrm{pH} 1-12$ for the samples with $\left.\mathrm{pH}<1.8, \mathrm{pH}=-\log c_{\mathrm{H}+}\right) .34$ samples were prepared for this purpose containing $\mathrm{Gd}^{3+}$ and the cddadpa ${ }^{4-}$ ligand at $1 \mathrm{~mm}$ concentration $(\mathrm{I}=0.15 \mathrm{~m})$. The samples were equilibrated for one day and their $T_{1}$ relaxation times were then recorded. The measurements were performed with a Bruker Minispec MQ20 NMR analyzer (20 $\left.\mathrm{MHz}, 25^{\circ} \mathrm{C}\right)$ using the inversion recovery method $\left(180^{\circ}-\tau-90^{\circ}\right)$ at 14 different $\tau$ values. The data were fitted by using the molar relaxivities of [Gd(cddadpa) $]^{-}$and $\mathrm{Gd}^{3+}$ determined independently (5.73 and 13.27 $\mathrm{mm}^{-1} \mathrm{~s}^{-1}$ at $25^{\circ} \mathrm{C}$ and $20 \mathrm{MHz}$, respectively) by using previously reported methods. These data were fitted simultaneously with the $\mathrm{pH}$-potentiometric titration data for the sample containing equimolar amounts of the ligand and $\mathrm{Gd}^{3+}$. The protonation and stability constants were calculated from the titration data with the PSEQUAD program. ${ }^{[28]}$ The $\mathrm{pGd}=-\log [\mathrm{Gd}]_{\text {free }}$ values of the complexes were calculated by using the protonation constants of the ligands and stability constants of the complexes at physiological $\mathrm{pH} 7.4$ using 10 $\mu \mathrm{m}$ ligand and $1 \mu \mathrm{m} \mathrm{Gd}^{3+}$ ion concentrations, as suggested by Raymond and co-workers. ${ }^{[20]}$

\section{$\underline{\text { Kinetic measurements }}$}

The rates of the metal exchange reactions involving the $[\mathrm{Gd}(\mathrm{cddadpa})]^{-}$complex and the $\mathrm{Cu}^{2+}$ ion were studied by using UV/Vis spectrophotometry following the formation of the $\left[\mathrm{Cu}_{2}\right.$ (cddadpa)] complex. The conventional UV/Vis spectroscopic method was applied to follow the decomplexation reactions of 
$[\mathrm{Gd}(\mathrm{cddadpa})]^{-}$as these reactions were very slow even at relatively low $\mathrm{pH}$. The absorbance vs. time kinetic curves were acquired by using a Jasco V-670 UV/Vis spectrophotometer equipped with Peltier thermostatted multicell holder. The temperature was maintained at $25^{\circ} \mathrm{C}$ and the ionic strength of the solutions was kept constant by using $0.15 \mathrm{~m} \mathrm{NaCl}$. For keeping the $\mathrm{pH}$ constant, 50 mmdimethylpiperazine (dmp) buffer was used ( $\log K_{2}{ }^{\mathrm{H}}=4.15(0.03)$ as determined by using $\mathrm{pH}$ potentiometry). The exchange reactions were followed at $310 \mathrm{~nm}$ in the $\mathrm{pH}$ range $3.38-4.96$ for $4-5$ days continuously (60-90\% conversion) while absorbance readings at equilibrium were determined by allowing the reactions to react for 3-4 weeks depending on the $\mathrm{pH}$ of the samples (8-10 times longer than the half-life of the reaction). The concentration of the [Gd(cddadpa) $]^{-}$complex was $0.311 \mathrm{~mm}$, while the $\mathrm{Cu}^{2+}$ ion was applied at high excess (11.1 to 40.9 -fold) guarantee pseudo-first order conditions. The absorbance vs. time reaction profiles could perfectly fitted by using the monoexponential function (Eq.):

$$
A_{\mathrm{t}}=\left(A_{0}-A_{\mathrm{e}}\right) \mathrm{e}^{-k_{\mathrm{obs}} t}+A_{\mathrm{e}}
$$

where $A_{\mathrm{t}}, A_{0}$, and $A_{\mathrm{e}}$ are the absorbance at time $t$, at the start, and at equilibrium, respectively. The pseudofirst-order rate constants were fitted with the computer program Micromath Scientist, version 2.0 (Salt Lake City, UT, USA) by using a standard least-squares procedure.

Dimethyl 6,6'-[\{(1 R,2 R)-cyclohexane-1,2-diylbis[\{2-(tert-butoxy)-2-oxoethyl\}azanediyl]\}bis(methylene)] dipicolinate (4): A mixture of $\mathbf{3}(1.00 \mathrm{~g}, 2.42 \mathrm{mmol}$ obtained as described in the Supporting Information) and $\mathrm{K}_{2} \mathrm{CO}_{3}(2.95 \mathrm{~g}, 21.3 \mathrm{mmol})$ in acetonitrile $(100 \mathrm{~mL})$ was stirred for $30 \mathrm{~min}$, and then tert-butyl-2bromoacetate $(0.99 \mathrm{~g}, 5.08 \mathrm{mmol})$ was added. The mixture was stirred at room temperature for 4 days under an inert atmosphere (Ar), and later at $45^{\circ} \mathrm{C}$ for a period of 3 days. The excess $\mathrm{K}_{2} \mathrm{CO}_{3}$ was filtered off, the filtrate was concentrated to dryness, and the yellow oil was extracted with a $1: 3$ mixture of $\mathrm{H}_{2} \mathrm{O}$ and $\mathrm{CHCl}_{3}(200 \mathrm{~mL})$. The organic phase was evaporated to dryness giving an oily residue that was purified by column chromatography on $\mathrm{SiO}_{2}$ with a $\mathrm{CH}_{2} \mathrm{Cl}_{2} / \mathrm{MeOH} 5 \%$ mixture as the eluent to give $1.01 \mathrm{~g}$ of $\mathbf{4}$ as a pale yellow oil. Yield $65 \%$; ${ }^{1} \mathrm{H}$ NMR $\left(500 \mathrm{MHz}, \mathrm{CDCl}_{3}, 25{ }^{\circ} \mathrm{C}\right.$, TMS): $\delta=8.05$ (d, ${ }^{3} J=7.8 \mathrm{~Hz}, 2 \mathrm{H}$ ), 7.94 (d, $\left.{ }^{3} J=7.8 \mathrm{~Hz}, 2 \mathrm{H}\right), 7.58\left(\mathrm{t},{ }^{3} \mathrm{~J}=7.8 \mathrm{~Hz}, 2 \mathrm{H}\right), 3.98(\mathrm{~s}, 6 \mathrm{H}), 3.92\left(\mathrm{~d},{ }^{2} \mathrm{~J}=15.1 \mathrm{~Hz}, 2 \mathrm{H}\right), 3.80\left(\mathrm{~d},{ }^{2} \mathrm{~J}=15.1 \mathrm{~Hz}\right.$, $2 \mathrm{H}), 3.38\left(\mathrm{~d},{ }^{2} \mathrm{~J}=16.8 \mathrm{~Hz}, 2 \mathrm{H}\right), 3.27\left(\mathrm{~d},{ }^{2} \mathrm{~J}=16.8 \mathrm{~Hz}, 2 \mathrm{H}\right), 2.64$ (m, $\left.2 \mathrm{H}\right), 2.13$ (m, $\left.2 \mathrm{H}\right), 1.74$ (m, $\left.2 \mathrm{H}\right), 1.43$ (s, $18 \mathrm{H}), 1.11 \mathrm{ppm}(\mathrm{m}, 4 \mathrm{H}) ;{ }^{13} \mathrm{C}$ NMR $\left(125.8 \mathrm{MHz}, \mathrm{CDCl}_{3}, 25^{\circ} \mathrm{C}, \mathrm{TMS}\right): \delta=171.3,166.0,161.7,146.7$, 136.9, 127.6, 123.5, 80.4, 61.6, 56.0, 52.8, 52.6, 28.1, 26.2, 25.9 ppm; IR (ATR): $\bar{\nu}=1721 \mathrm{~cm}^{-1}(\mathrm{C}=\mathrm{O})$; HRMS (ESI ${ }^{+}, \mathrm{MeOH}: \mathrm{CH}_{3} \mathrm{CN}: \mathrm{H}_{2} \mathrm{O}$ 9:1:1): $\mathrm{m} / z$ calcd for $\left[\mathrm{C}_{34} \mathrm{H}_{49} \mathrm{~N}_{4} \mathrm{O}_{8}\right]^{+}:$641.3544; found: 641.3554; elemental analysis calcd (\%) for $\mathrm{C}_{34} \mathrm{H}_{48} \mathrm{~N}_{4} \mathrm{O}_{8}$ : C 63.73, H 7.55, N 8.74; found: $\mathrm{C} 64.02, \mathrm{H}$ 7.54, N 8.86.

6,6'-[\{(1 R,2 R)-Cyclohexane-1,2-diylbis[(carboxymethyl)azanediyl]\}bis(methylene)]dipicolinic acid $\left(\mathbf{H}_{4}\right.$ cddadpa $\left.3 \mathbf{H C l} \cdot \mathbf{2} \mathbf{H}_{2} \mathrm{O}\right)$ : A solution of compound $4(1.01 \mathrm{~g}, 1.58 \mathrm{mmol})$ in $6 \mathrm{~m} \mathrm{HCl}(50 \mathrm{~mL})$ was heated to reflux for $24 \mathrm{~h}$, and then the solvent was removed in a rotary evaporator to give a yellow oil. A small amount of $\mathrm{H}_{2} \mathrm{O}$ was added (ca. $20 \mathrm{~mL}$ ) and the mixture evaporated to dryness. This process was repeated once with addition of $\mathrm{H}_{2} \mathrm{O}$ and twice with addition of diethyl ether (ca. $20 \mathrm{~mL}$ ), returning $0.77 \mathrm{~g}$ of the desired ligand as a dark yellow solid. Yield $75 \%$; ${ }^{1} \mathrm{H}$ NMR $\left(500 \mathrm{MHz}, \mathrm{D}_{2} \mathrm{O}, \mathrm{pD} 2.5,25{ }^{\circ} \mathrm{C}\right.$, TMS $): \delta=8.10$ $7.86(\mathrm{~m}, 6 \mathrm{H}), 4.26-3.35(\mathrm{~m}, 10 \mathrm{H}), 2.22(\mathrm{~m}, 2 \mathrm{H}), 1.83(\mathrm{~m}, 2 \mathrm{H}), 1.45(\mathrm{~m}, 2 \mathrm{H}), 1.29 \mathrm{ppm}(\mathrm{m}, 2 \mathrm{H}) ;{ }^{13} \mathrm{C}$ NMR (125.8 MHz, $\left.\mathrm{D}_{2} \mathrm{O}, \mathrm{pD} 2.5,25^{\circ} \mathrm{C}, \mathrm{TMS}\right): \delta=171.4,164.9,152.3,145.2,129.4,125.7,125.6,62.4,52.7$, 50.5, 23.8 ppm; IR (ATR): $\bar{\nu}=1714,1627 \mathrm{~cm}^{-1}(\mathrm{C}=\mathrm{O})$; MS (ESI $, \mathrm{MeOH}: \mathrm{CH}_{3} \mathrm{CN}_{2}: \mathrm{H}_{2} \mathrm{O}$ 9:1:1): $\mathrm{m} / z 539$ $\left[\mathrm{C}_{24} \mathrm{H}_{28} \mathrm{KN}_{4} \mathrm{O}_{8}\right]^{+}$; elemental analysis calcd (\%) for $\mathrm{C}_{24} \mathrm{H}_{28} \mathrm{~N}_{4} \mathrm{O}_{8} \cdot 3 \mathrm{HCl} \cdot 2 \mathrm{H}_{2} \mathrm{O}: \mathrm{C} 44.63, \mathrm{H}$ 5.46, N 8.67; found: C 44.46, H 5.41, N 8.49. 


\section{Acknowledgements}

M.R.-F., D.E.-G., and C.P.-I. thank Universidade da Coruña for generous financial support. The authors gratefully acknowledge the support from the Hungarian Scientific Research Fund (OTKA K-84291 and K109029), the Ligue contre le Cancer (France), and the TÁMOP-4.2.2A-11/1/KONV-2012-0043 (ENVIKUT) project implemented through the New Hungary Development Plan, co-financed by the European Social Fund and the European Regional Development Fund. G.T. and É.T. are indebted to the Hungarian-French bilateral Scientific and Technological Cooperation (project TÉT_11-2-2012-0010 and PHC Balaton) and COST TD1004 "Theragnostics Imaging and Therapy: An Action to Develop Novel Nanosized Systems for Imaging-Guided Drug Delivery" Action for founding Short Term Scientific Missions of the researchers. This work was also supported by the János Bolyai Research Scholarship (Gy.T. and F.K.K.) of the Hungarian Academy of Sciences.

[1] S. Cheng, L. Abramova, G. Saab, G. Turabelidze, P. Patel, M. Arduino, T. Hess, A. Kallen, M. Jhung, JAMA 2007, 297, 1542-1544.

[2] The Chemistry of Contrast Agents in Medical Magnetic Resonance Imaging (Eds: A. E. Merbach, L. Helm, É. Tóth), Wiley, Hoboken, 2013, second Ed.

[3] E. Toth, E. Brucher, I. Lazar, I. Toth, Inorg. Chem. 1994, 33, 4070-4076.

[4] L. Sarka, L. Burai, E. Brücher, Chem. Eur. J. 2000, 6, 719-724.

[5] a) Z. Baranyai, E. Brucher, F. Uggeri, A. Maiocchi, I. Toth, M. Andrasi, A. Gaspar, L. Zekany, S. Aime, Chem. Eur. J.2015, 21, 4789-4799; b) Z. Baranyai, Z. Palinkas, F. Uggeri, A. Maiocchi, S. Aime, E. Brucher, Chem. Eur. J. 2012, 18, 16426-16435.

[6] a) M. Polasek, P. Caravan, Inorg. Chem. 2013, 52, 4084-4096; b) Z. Pálinkás, A. Roca-Sabio, M. MatoIglesias, D. Esteban-Gómez, C. Platas-Iglesias, A. de Blas, T. Rodríguez-Blas, E. Tóth, Inorg. Chem. 2009, 48, 8878-8889.

[7] A. Pasha, G. Tircso, E. T. Benyo, E. Brucher, A. D. Sherry, Eur. J. Inorg. Chem. 2007, 4340-4349.

[8] a) T. Ryhl, Acta Chem. Scand. 1972, 26, 3955-3968; b) G. A. Nyssen, D. W. Margerum, Inorg. Chem. 1970, 9, 1814-1820; c) E. Brücher, P. Szarvas, Inorg. Chim. Acta 1970, 4, 632-636.

[9] F. K. Kálmán, G. Tircso, Inorg. Chem. 2012, 51, 10065-10067.

[10] E. M. Gale, N. Kenton, P. Caravan, Chem. Commun. 2013, 49, 8060-8062.

[11] C. S. Bonnet, S. Laine, F. Buron, G. Tircsó, A. Pallier, L. Helm, F. Suzenet, É. Tóth, Inorg. Chem. 2015, 54, 5991-6003.

[12] a) C. Wu, H. Kobayashi, B. Sun, T. M. Yoo, C. H. Paik, O. A. Gansow, J. A. Carrasquillo, I. Pastan, M. W. Brechbiel, Bioorg. Med. Chem. 1997, 5, 1925-1934; b) T. J. McMurry, C. G. Pippin, C. Wu, K. A. Deal, M. W. Brechbiel, S. Mirzadeh, O. A. Gansow, J. Med. Chem. 1998, 41, 3546-3549.

[13] A. Rodriguez-Rodriguez, D. Esteban-Gomez, R. Tripier, G. Tircso, Z. Garda, I. Toth, A. de Blas, T. Rodriguez-Blas, C. Platas-Iglesias, J. Am. Chem. Soc. 2014, 136, 17954-17957. 
[14] E. W. Price, B. M. Zeglis, J. F. Cawthray, J. S. Lewis, M. J. Adam, C. Orvig, Inorg. Chem. 2014, 53, 10412-10431.

[15] F. K. Kálmán, A. Vegh, M. Regueiro-Figueroa, E. Toth, C. Platas-Iglesias, G. Tircso, Inorg. Chem. 2015, 54, 2345-2356.

[16] C. Platas-Iglesias, M. Mato-Iglesias, K. Djanashvili, R. N. Muller, L. Van der Elst, J. A. Peters, A. de Blas, T. Rodríguez-Blas, Chem. Eur. J. 2004, 10, 3579-3590.

[17] R. M. Smith, A. E. Martell, R. J. Motekaitis, NIST critically selected stability constants of metal complexes database, version 8.0, Texas A\&M University, 2004.

[18] Z. Baranyai, Z. Palinkas, F. Uggeri, E. Brücher, Eur. J. Inorg. Chem. 2010, 1948-1956.

[19] E. Brücher, G. Tircsó, Z. Baranyai, Z. Kovács, A. D. Sherry, Stability and Toxicity of Contrast Agents, in The Chemistry of Contrast Agents in Medical Magnetic Resonance Imaging, Second Edition, (Eds.: A. E. Merbach, L. Helm, É. Tóth), Wiley, Hoboken, 2013, ch. 4, pp. 157-208.

[20] J. Xu, S. J. Franklin, D. W. Whisenhunt, K. N. Raymond, J. Am. Chem. Soc. 1995, 117, 7245-7246.

[21] A. Takács, R. Napolitano, M. Purgel, A. C. Bényei, L. Zékány, E. Brücher, I. Tóth, Z. Baranyai, S. Aime, Inorg. Chem.2014, 53, 2858-2872.

[22] a) G. Tircsó, Z. Kovács, A. D. Sherry, Inorg. Chem. 2006, 45, 9269-9280; b) L. Pellegatti, J. Zhang, B. Drahos, S. Villette, F. Suzenet, G. Guillaumet, S. Petoud, É. Tóth, Chem. Commun. 2008, 6591-6593.

[23] K. Kumar, T. Jin, X. Wang, J. F. Desreux, M. F. Tweedle, Inorg. Chem. 1994, 33, 3823-3829.

[24] A. Beeby, I. M. Clarkson, R. S. Dickins, S. Faulkner, D. Parker, L. Royle, A. S. de Sousa, J. A. G. Williams, M. Woods, J. Chem. Soc. Perkin Trans. 1999, 493-503.

[25] R. M. Supkowski, W. D. W. Horrocks Jr, Inorg. Chim. Acta 2002, 340, 44-48.

[26] E. Balogh, M. Mato-Iglesias, C. Platas-Iglesias, É. Toth, K. Djanashvili, J. A. Peters, A. de Blas, T. Rodriguez-Blas, Inorg. Chem. 2006, 45, 8719-8728.

[27] H. M. Irving, M. G. Miles, L. Pettit, Anal. Chim. Acta 1967, 38, 475-488.

[28] L. Zékány, I. Nagypál in Computational Method for Determination of Formation Constants, (Ed. D. J. Legett), Plenum, New York, 1985, p. 291. 